\title{
Strengthening social inclusion within oil palm contract farming in the Brazilian Amazon
}

\author{
Frederico Brandão, George Schoneveld and Pablo Pacheco
}

\section{Key messages}

- Despite its promotion of contract farming (widely considered to be a relatively pro-poor approach to agribusiness expansion), Brazil's Sustainable Palm Oil Production Program (SPOPP) cannot be considered to be an inclusive development program in its current format. Findings suggest that land- and labor-constrained households are more likely to be excluded from contract farming under this program than other households.

- Viable options to strengthen inclusivity within the program include permitting smallholders to develop smaller plantations, promoting intercropping and reducing barriers that currently prevent smallholders under the scheme from engaging external laborers.

- Despite civil society concerns that contract farming could result in smallholders abandoning staple food crop production to focus only on oil palm, there is no evidence to date that contract farming under the SPOPP scheme has exacerbated smallholder food insecurity.

- Results suggest that while smallholder performance ranges widely, from highly productive farms to near abandonment of oil palm plots, the majority of smallholders involved in the scheme have been unable to meet the performance expectations of oil palm companies.

- To increase the likelihood of success amongst the $12 \%$ of smallholders at highest risk of credit default, additional support should be provided, for example in the form of targeted capacity-building initiatives or enabling management outsourcing arrangements where successful smallholders take over plantation management through production sharing arrangements.

\section{Introduction}

In 2010, the Brazilian government launched the Sustainable Palm Oil Production Program (SPOPP) to promote sustainable palm oil production in the Amazon, as part of the strategy to stimulate biofuel production. SPOPP sought to prevent Brazil's palm oil sector experiencing the negative socio-economic and environmental impacts that have long plagued the country's sugarcane sector and palm oil production in Southeast Asia. The scheme was also intended to leverage the crop's potential to contribute to land rehabilitation and rural development (Andrade and Miccolis 2011).
Among SPOPP's strategies to achieve these objectives, is the promotion of contract farming. This was largely inspired by the success of a smallholder scheme implemented by one of Brazil's leading oil palm companies, Agropalma, in the state of Pará. Its implementation was supported by two closely related initiatives, namely the Social Fuel Seal, which provides companies involved in biofuel production with fiscal incentives and other benefits in return for sourcing from smallholders, and the National Program for Strengthening Family Agriculture (PRONAF ECO), a smallholder credit initiative for oil palm farmers. To ensure oil palm expansion is not a (direct) driver of deforestation, SPOPP restricts conversion of primary forests and lands in protected areas, through its AgroEcological Zoning of Oil Palm in Deforested Areas of the Amazon (ZAE-Palma). 
Contract farming is widely viewed as a comparatively pro-poor form of agribusiness expansion, however whether it wholly corresponds with rural development objectives is debatable (Barrett et al. 2012; Cahyadi and Waibel 2013). On the one hand, it might help resolve problems relating to poor access to quality production inputs, credit, technical assistance and stable markets in the Amazon. On the other hand, contract farming is rarely fully inclusive of more marginalized groups and, in the specific case of oil palm in the Brazilian Amazon, may increase the risk of credit default and food insecurity amongst smallholders, whilst undermining livelihood diversification. Drawing on key informant interviews and 420 surveys with participants and non-participants of oil palm contracting farming schemes in Brazil's largest oil palm producing state, Pará, this brief offers new insights into the extent these opportunities and risks play out, in the case of
SPOPP. In so doing, we offer preliminary insights into the social performance of SPOPP, and oil palm more generally in Brazil.

\section{Oil palm expansion in Brazil}

Oil palm expansion in Brazil is partly a product of governmental policies. In recent decades, oil palm production has benefitted from both subsidies and tax incentives, with the objective of incorporating the Amazon's agricultural frontiers into the Brazilian economy. By 1999, five companies dominated the sector, sourcing primarily from their own plantations and medium-sized farms owned by producers of Japanese descent. The total planted area spanned approximately 63,000 ha in Pará, Brazil's largest producing state (Venturieri 2011).

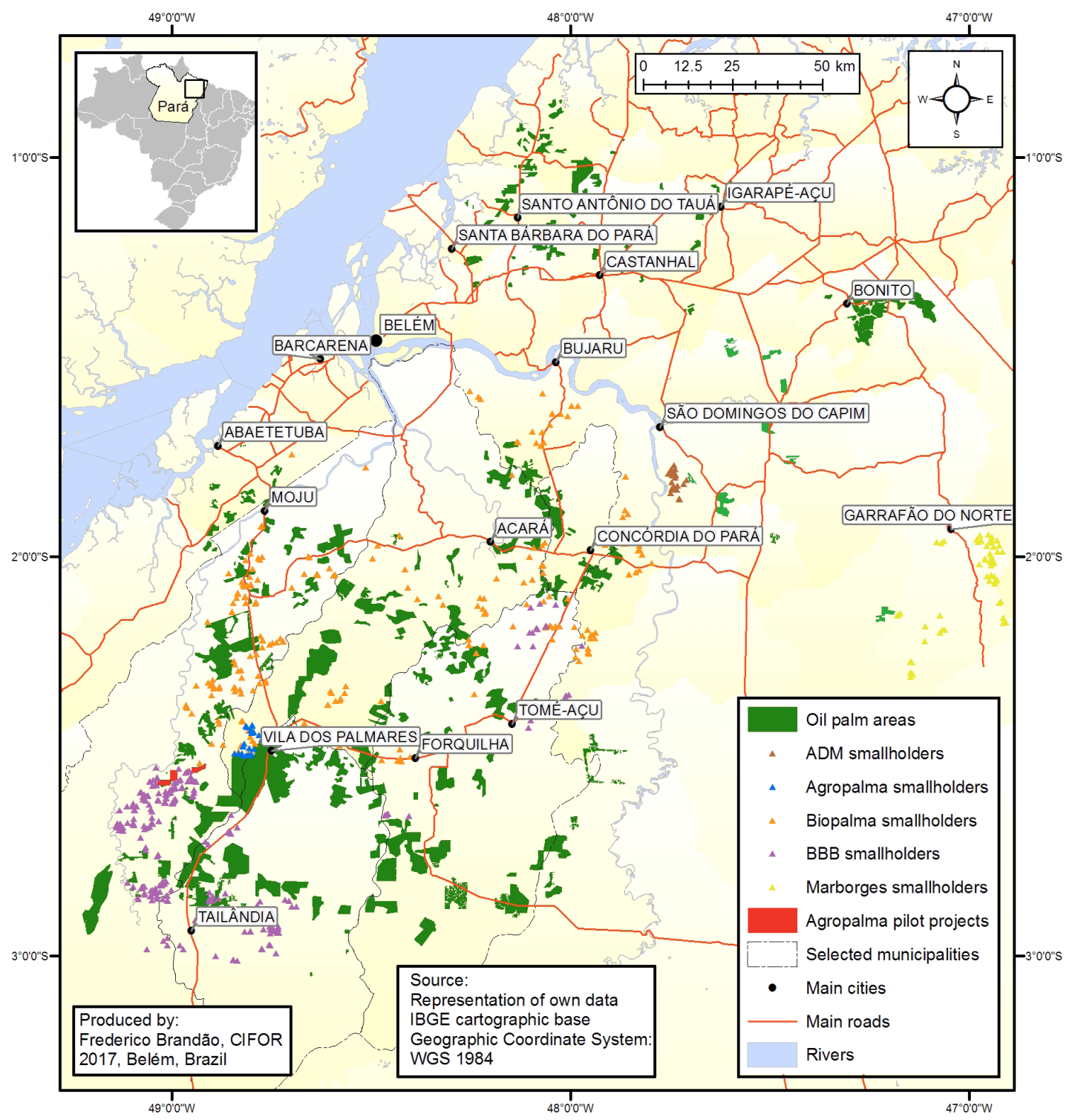

Figure 1. Distribution of oil palm production in Pará 
The sector received new impetus in the mid-2000s, when the federal government began promoting biodiesel production for the national market. This resulted in the Biodiesel Production and Use Program and SPOPP (established in 2004 and 2010 respectively), predominantly as a strategy to diversify the biodiesel feedstock. These incentives resulted in an influx of new large investors, which included the Brazilian mining giant Vale (Biopalma), the US-based grain company ADM, and a joint venture between the Brazilian petroleum company Petrobras and the Portuguese petroleum company Galp (Project Belém Bioenergia Brasil, BBB). Through these investments, the area under cultivation more than tripled; reaching 207,000 ha in 2017 (see Figure 1 for oil palm distribution in Pará). Third party sourcing (outgrowers) accounted for approximately $20 \%$ of this area; these were made up of 1,508 farming families and 181 medium-scale producers, the latter being employed under ad hoc contracts or, in some cases, relying on verbal agreements (Abrapalma 2017). In 2015, however, sector expansion ceased, in the context of political instability and unfavorable economic and market conditions, which had given rise to concerns about the competitiveness and future of Brazil's oil palm industry.

\section{How inclusive is SPOPP?}

Farmers willing to participate in oil palm contract farming are required to comply with a wide range of eligibility criteria, including PRONAF Eco credit access conditions, and company-specific requirements (Table 1). These criteria derive in part from civil society concerns over food security (e.g. conversion of staple crops like cassava to oil palm), company concerns over productivity and profitability, financial institution concerns over credit default, and government concerns over land use management (Brandão and Schoneveld 2015).

While research findings suggest that during the early implementation of SPOPP many of these criteria were only selectively applied, and company managers identified previous credit defaults as a primary participation determinant, our probit model analysis demonstrates that availability of land and labor resources (at a household level) also strongly shapes patterns of inclusion and exclusion (see Table 2). This can be explained by landand labor-constrained groups voluntarily opting out of participating, and likewise, by these same groups being involuntarily excluded as a result of ineligibility. Some companies contend that land- and labor-poor households are not competitive, since they will not be able to devote sufficient resources to palm oil production. Other factors shaping participation are education and membership in a community association. More educated households, and households that are better integrated into their communities, likely have more confidence cultivating a new crop and taking out the comparatively large loans required.
Table 1. SPOPP's contract farming scheme inclusion criteria

\begin{tabular}{ll}
\hline PRONAF Eco criteria & Company-specific criteria \\
\hline $\begin{array}{l}\text { Able to plant up to (a } \\
\text { maximum of) 10 ha of } \\
\text { oil palm }\end{array}$ & $\begin{array}{l}\text { In possession of (normally) } \\
10 \text { ha of land suitable for } \\
\text { oil palm production (some } \\
\text { companies accept less than } \\
10 \text { ha and avoid conflict with } \\
\text { food crops) }\end{array}$ \\
\hline $\begin{array}{l}\text { Certified 'farming family' } \\
\text { (through a Declaration of }\end{array}$ & $\begin{array}{l}\text { Able to demonstrate financial } \\
\text { and crop management } \\
\text { captitude) with annual income and availability } \\
\text { exceeding USD 6,250 }\end{array}$ \\
$\begin{array}{ll}\text { of sufficient capable } \\
\text { household labor }\end{array}$ \\
$\begin{array}{l}\text { Ruperty registered in the } \\
\text { and with ZAE-Palma }\end{array}$ & $\begin{array}{l}\text { Access to roads, located } \\
\text { within certain distance of the } \\
\text { company mill, with possibility } \\
\text { of forming farmer clusters }\end{array}$ \\
\hline $\begin{array}{l}\text { Signed outgrower contract } \\
\text { and documentation proving } \\
\text { property ownership, } \\
\text { partnership or 'peaceful' } \\
\text { possession }\end{array}$ & $\begin{array}{l}\text { Ownership of at least 25 ha } \\
\text { of land }\end{array}$ \\
\hline $\begin{array}{l}\text { Not black-listed as a credit } \\
\text { defaulter }\end{array}$ & $\begin{array}{l}\text { Compliance with RSPOa } \\
\text { relevant principles and } \\
\text { criteria (some companies) }\end{array}$ \\
\hline
\end{tabular}

a The Roundtable on Sustainable Palm Oil (RSPO) is a multi-stakeholder platform engaging oil palm producers, banks and civil society organizations. RSPO has created a set of certification rules (Principals and Criteria), including several environmental and social safeguards, which are adapted to each country through national interpretations and allow companies to claim to be certified oil palm (CSPO) producers and access premium markets.

\section{Table 2. Oil palm contract farming inclusion determinants}

\begin{tabular}{ll}
\hline Variable & Results \\
\hline Age of household head & None \\
\hline Gender of the person in charge & None \\
\hline Household's highest educational level & Positive \\
\hline Dependency ratio & Negative \\
\hline $\begin{array}{l}\text { Number of persons contributing to the } \\
\text { Household }\end{array}$ & Positive \\
\hline Land area & Positive \\
\hline Degree of crop diversification & None \\
\hline Degree of livelihood diversification & None \\
\hline Household wealth & None \\
\hline Member of community association & Positive \\
\hline Prior experience with oil palm & None \\
\hline
\end{tabular}




\section{Do labor-constrained households devote less time to plantation management?}

As availability of household labor is one of the primary reasons that willing participants are excluded, we tested the assumption that having more household labor available does, in reality, contribute to more time being devoted to plantation management. Our analysis', clearly shows that labor allocation is primarily dependent on a household's willingness or ability to hire labor (Table 3). This willingness or ability increases when households are labor and land poor, and offsets the negative influence of high ratios of dependency. Thus, labor-constrained households do not necessarily devote less time to plantation management. Since PRONAF Eco credits include a payment of approximately USD 225 per ha per year for crop management, labor-constrained groups tend to use this money to hire labor. However, as company managers and farmers have pointed out, there is a limitation in the SPOPP design, as the fixed stipend covers labor costs up to the third year, while smallholders only reach viable productivity after the fourth or fifth year.

Table 3. Determinants of household time allocation to oil palm

\begin{tabular}{ll}
\hline Variable & Result \\
\hline Age of household head & None \\
\hline Education of household head & None \\
\hline Gender of the person in charge & None \\
\hline Dependency ratio & Negative \\
\hline Number of persons contributing to the & None \\
\hline household & None \\
\hline Land area owned & None \\
\hline Degree of crop diversification & Positive \\
\hline Harvesting of oil palm commenced & None \\
\hline Participation in trainings & None \\
\hline Distance of dwelling to farm & None \\
\hline Prior experience with oil palm & Positive \\
\hline Hiring external labor &
\end{tabular}

1 We adopted an endogenous switching regression model by full information maximum likelihood in order to control for endogeneity. In econometrics, an endogeneity problem occurs when explanatory variables are correlated with the error term. Endogeneity can arise as a result of measurement error, autoregression with autocorrelated errors, simultaneous causality, omitted selection, and omitted variables.

\section{Does oil palm production drive specialization and increase food insecurity?}

Due to oil palm's high labor intensity and comparatively high returns compared to alternative livelihood options in the region (Brandão and Schoneveld 2015), some critics have posited that households may choose or be forced to abandon or neglect other livelihood activities (most critically, production of staple food crops such as cassava) and specialize in oil palm production (Glass 2013). This action could undermine household food security and increase vulnerability to shocks; more critical in a context where water shortfalls resulted in losses of up to $40 \%$ of oil palm fruit between 2015 and 2016. Our results however give reason to question this assumption; no such effects have yet been observed amongst SPOPP farmers. For example, household land and human capital endowments were found to be the primary diversification determinants. No statistically significant difference could be observed between SPOPP participants and non-participants on this, nor locally-relevant food security indicators. Nonetheless, this situation may still change over time ${ }^{2}$

Table 4. Differences between participants and nonparticipants of SPOPP

\begin{tabular}{ll}
\hline Variable & Results \\
\hline Degree of livelihood diversification & None \\
\hline Degree of crop diversification & None \\
\hline Proportion farmers cultivating cassava & None \\
\hline Stop cassava cultivation in last five years & None \\
\hline Cassava production volume & None \\
\hline Ability to meet household food needs & None \\
\hline Calories produced per person per day & None \\
\hline
\end{tabular}

2 Our results indicate differences amongst pre-SPOPP farmers (e.g. those entering into contract farming arrangements prior to the establishment of SPOPP), giving reason to reflect on possible longer-term trends favoring specialization. Pre-SPOPP households are comparatively specialized in oil palm, less likely to produce the region's most important staple crop (cassava) than SPOPP and non-participant households and have also proven more likely to abandon and/or reduce cassava production over the past five years. This could be explained by differences in crop maturity, as pre-SPOPP farmers have been able to benefit from regular income flows provided by oil palm for a longer time, or the contract farming scheme design, given its strong emphasis on encouraging farmers to continue producing other crops. 


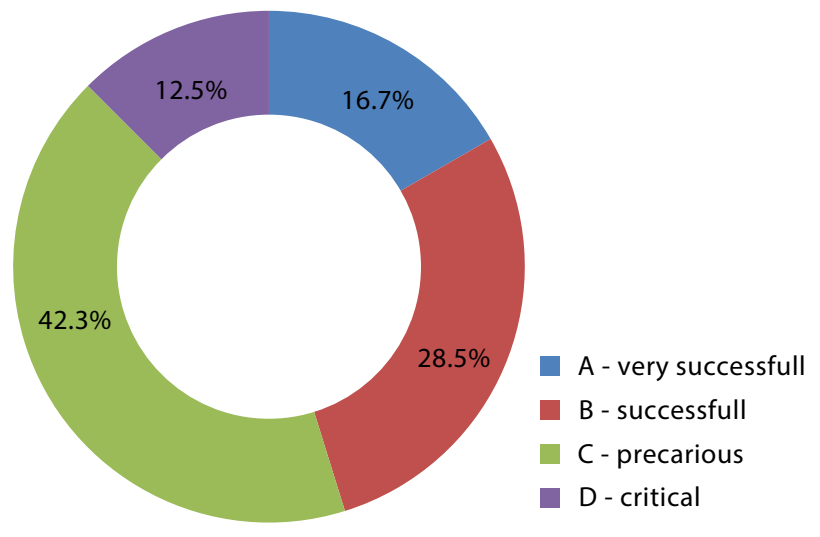

Figure 2. Performance of SPOPP farmers

\section{Should we worry about credit default?}

Data was collected on farmer productivity and quality of crop management practices from the three largest oil palm companies in Pará, which collectively source from approximately two-thirds of Para's oil palm contract farmers. The companies helped us divide up the 1,031 participants into four groups based on performance. Group A contained motivated farmers that adopt best management practices, with above average productivity. Group B consisted of average farmers with average productivity, while Group C consisted of farmers with below average productivity, who typically failed to devote the necessary time to oil palm or lacked the capacity to comply with agronomic guidelines. Finally, Group D was made up of farmers that (typically due to personal issues) were systemically neglecting/had abandoned their plantations. The results (presented in Figure 2) show wide differences across farmers' performances, ranging from complete success (Group A: 17\%) to near abandonment (Group D: 12\%). However, the majority of farmers (54\%) failed to meet productivity expectations, with companies expressing concerns about the capacity of these farmers to develop economically viable oil palm operations over time and, thus, be able to fulfill their debt obligations ${ }^{3}$. This is particularly critical within Group D. As the oil palms of most SPOPP farmers are yet to reach maturity, it is yet to be seen if oil palm production for these farmers will become a more profitable and desirable source of household income. However, with a number of major oil palm companies facing difficulties in making a profit due to the recent economic and social challenges nationally, the quality of extension services and input support has suffered, in some instances. The performance of farmers that fail to meet standards may, as a result, suffer further.

3 As farmers are required to commence loan repayments after six years, few have yet defaulted, since they are still within their grace period.

\section{Conclusion and recommendations}

Results show that SPOPP is not particularly inclusive of smallholders and tends to exclude marginalized groups; these more marginalized smallholders are unable to benefit from oil palm's income-generating potential, typically because they lack the required land and labor resources. However, our analysis suggests that availability of labor within the household may not be necessary for inclusion; instead the capacity to hire labor is a more important determinant of whether or not labor is allocated to plantation management. Additionally, our results question the assumption that oil palm adoption could result in crop specialization, and thereby undermine household food security. However, our results do suggest that oil palm production, at least in the format it has been promoted by SPOPP and implemented by companies, may not be a desirable livelihood option for all; the majority (55\%) of farmers fails to meet company performance expectations, and some (12\%) are at high risk of future credit default. This may be overcome by supporting households that lack capacity to effectively navigate local labor markets, or by adjusting plantation size or production systems.

Based on this, we recommend the following:

- Permitting smaller plantation sizes to include land- and labor-constrained groups. Decreasing economies of scale deriving from smaller plantations should, however, be compensated by strengthening efficiency, for example through logistical improvements.

- $\quad$ Allowing smallholders with smaller land areas to participate in SPOPP; for example, by promoting oil palm intercropping systems that enable smallholders to remain diversified, whilst reducing the risk of undesirable land use competition with food and other crops. Diversification should, however, be promoted with caution, since it is more labor intensive than monocrop systems.

- $\quad$ Providing technical support to farmers engaging with local labor markets, and/or facilitating 'match-making', i.e. linking farmers to laborers.

- $\quad$ Strengthening the credit design clause that specifies a fixed stipend to cover labor costs until the third year and extend this up to five years (based on performance) to facilitate the inclusion of laborconstrained groups.

- $\quad$ Preventing farmers at high risk of credit default (Group D) from abandoning their oil palm projects, for example by enabling outsourcing arrangements (e.g. where successful smallholders take over plantation management through production sharing arrangements) or through extra targeted technical support and capacity building. 


\section{Acknowledgements}

This research was conducted with the financial support of the DfID-funded KnowFOR (Forestry Knowledge) program. This work is part of the CGIAR Research Program on Forests, Trees and Agroforestry (FTA). This research is supported by CGIAR Fund Donors. For a list of Fund donors, please see: www.cgiar.org/ about-us/our-funders/. The authors would like to acknowledge Túlio Dias, Alfredo Homma and Trent Blaire for their valuable comments on a previous version of this document.

\section{References}

Abrapalma. 2017. Números de produção Agosto 2016. Unpublished dataset.

Andrade RMT and Miccolis A. 2011. Policies and institutional and legal frameworks in the expansion of Brazilian biofuels. Bogor, Indonesia: Center for International Forestry Research.
Barrett CB, Bachke ME, Bellemare MF, Michelson HC, Narayanan S and Walker TF. 2012. Smallholder participation in contract farming: Comparative evidence from five countries. World Development 40:715-730.

Brandão F and Schoneveld G. 2015. The state of oil palm development in the Brazilian Amazon: Trends, value chain dynamics and business models. Bogor, Indonesia: Center for International Forestry Research.

Cahyadi ER and Waibel H. 2013. Is contract farming in the Indonesian oil palm industry pro-poor? Journal of Southeast Asian Economies 30:62-76.

Glass V. 2013. Expansão do dendê na Amazônia brasileira: Elementos para uma análise dos impactos sobre a agricultura familiar no nordeste do Pará. São Paulo: Repórter Brasil.

Venturieri A. 2011. Evolução da área plantada com palma de óleo no Brasil, com ênfase no estado do Pará. Agroenergia em revista 2:18. http://en.calameo.com/ read/0005121679cb44d799a7d
The CGIAR Research Program on Forests, Trees and Agroforestry (FTA) is the world's largest research for development program to enhance the role of forests, trees and agroforestry in sustainable development and food security and to address climate change. CIFOR leads FTA in partnership with Bioversity International, CATIE, CIRAD, ICRAF, INBAR and TBI.

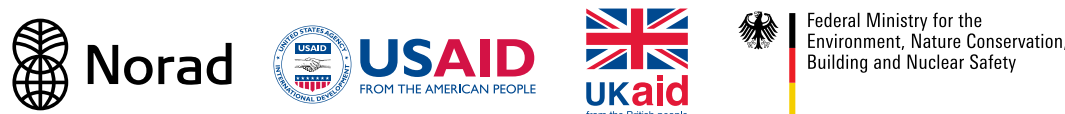

